\title{
Pengaruh Citra Merek Terhadap Kepuasan Pelanggan dan Implikasinya pada Positive Word Of Mouth Penumpang MRT
}

\author{
Jakarta \\ Meiliana, Rezi Erdiansyah \\ Meiliana0805@gmail.com,Rezie@fikom.untar.ac.id \\ Fakultas Ilmu Komunikasi Universitas Tarumanagara
}

\begin{abstract}
The purpose of this study was to determine the effect of brand image on positive word of mouth through Jakarta MRT passenger satisfaction. The research sample used as many as 125 respondents came from passengers aged 20 years over and had used the Jakarta MRT services. Questionnaires were distributed and filled out directly by respondents and by Google forms. Data analysis using SPSS (Statistical Package For The Social Sciences) version 23 software and SEM (Structural Equation Modeling) with Lisrel application version 8.80. The results showed brand image and customer satisfaction had a significant influence on positive word of mouth MRT Jakarta passengers. However, customer satisfaction is most influential on positive word of mouth, then followed by brand image. In sequence the most dominant dimensions that shape brand image are value, corporate identity, reputation and personality. Furthermore, sequentially the most dominant dimensions that shape customer satisfaction are service quality, product quality, price and comfort. And in sequence the most dominant dimensions that make up positive word of mouth are information, invitations, recommendations and positive stories. Thus, to create positive word of mouth, efforts should be made to increase customer satisfaction.
\end{abstract}

Keywords: brand image, customer satisfaction, mrt jakarta, positive word of mouth.

\begin{abstract}
Abstrak
Tujuan dari penelitian ini adalah untuk mengetahui pengaruh citra merek terhadap positive word of mouth melalui kepuasan penumpang MRT Jakarta. Sampel penelitian yang digunakan sebanyak 125 responden berasal dari penumpang yang berumur 20 tahun ke atas dan pernah menggunakan jasa layanan MRT Jakarta. Kuesioner disebarkan melalui penyebaran angket dan diisi langsung oleh responden serta google forms. Analisis data menggunakan aplikasi SPSS (Statistical Package For The Social Sciences) versi 23 dan SEM (Structural Equation Modeling) dengan aplikasi Lisrel versi 8.80. Hasil penelitian menunjukkan citra merek dan kepuasan pelanggan memberikan pengaruh signifikan terhadap positive word of mouth penumpang MRT Jakarta. Namun demikian, kepuasan pelanggan paling berpengaruh terhadap positive word of mouth, lalu diikuti dengan citra merek. Secara berurutan dimensi paling dominan yang membentuk citra merek adalah nilai, identitas perusahaan, reputasi dan kepribadian. Selanjutnya, secara berurutan dimensi paling dominan yang membentuk kepuasan pelanggan adalah kualitas pelayanan, kualitas produk, harga dan kenyamanan. Dan secara berurutan dimensi paling dominan yang membentuk positive word of mouth adalah informasi, ajakan, rekomendasi dan cerita positif. Dengan demikian, untuk menciptakan positive word of mouth perlu dilakukan upaya meningkatkan kepuasan pelanggan.
\end{abstract}

Kata Kunci: citra merek, kepuasan pelanggan, mrt jakarta, positive word of mouth. 


\section{Pendahuluan}

Pada dasarnya manusia sebagai makhluk sosial yang tidak pernah lepas dari kegiatan komunikasi dan pemasaran dalam menjalankan kehidupan sehari-hari. Menurut Sukoco (2018) ilmu komunikasi adalah ilmu yang sangat luas dan selalu berkaitan dengan berbagai jenis ilmu lainnya, salah satunya perpaduan komunikasi dan bisnis yang disebut sebagai komunikasi pemasaran.

Dalam pemasarannya perusahaan memerlukan strategi untuk memperkenalkan produknya. Menurut Latief (2018) perusahaan memerlukan strategi kegiatan komunikasi dengan mengelola kemampuan berkomunikasi dan memanfaatkan sarana komunikasi yang tersedia, atau dengan menciptakan strategi komunikasi dalam memasarkan produk atau jasanya pada konsumen. Dalam melakukan kegiatan komunikasi tersebut perusahaan dapat melakukan komunikasi word of mouth.

Menurut Sugianto (2016) word of mouth adalah komunikasi informal tentang produk atau jasa, berbeda dengan komunikasi formal, karena dalam komunikasi informal komunikator cenderung bertindak sebagai seorang teman yang lebih persuasif. Selanjutnya, Sallam (2014:189) menyatakan bahwa word of mouth paling sedikit dilakukan oleh dua orang konsumen, tanpa niat komersial, berkomunikasi tatap muka mengenai merek, produk atau layanan. Menurut Prasetyo et. al (2018:202) patut disadari terdapat dua sifat word of mouth, yaitu positive word of mouth yang dapat mengangkat nama brand dan negative word of mouth yang dapat menjatuhkan posisi brand.

Untuk itu, peneliti akan mengkaji positive word of mouth yang dapat mengangkat brand sebuah perusahaan. Menurut Kotler dan Keller (dalam Santoso, et.al 2018) citra merek merupakan perpaduan dari keseluruhan identitas perusahaan yang berbeda dengan pesaingnya. Mira, et.al (2014) menemukan bahwa citra merek mempengaruhi konsumen melakukan word of mouth. Selain itu, Popp (2017:) juga menemukan bahwa citra merek, kepuasan pelanggan dan harga berpengaruh positif terhadap positive word of mouth.

Peneliti tidak menemukan jurnal yang memiliki bahasan khusus pengaruh citra merek dan kepuasan pelanggan terhadap positive word of mouth. Untuk itu, peneliti akan mengkaji pengaruh citra merek dan kepuasan pelanggan terhadap positive word of mouth penumpang MRT Jakarta. Menurut Lovelock dan Wirtz (dalam Putri dan Suhariadi 2013) perusahaan jasa memiliki skala pengalaman dan kepercayaan yang tinggi sehingga konsumen yang kurang dalam informasi mengenai suatu jasa lebih bergantung pada word of mouth dibandingkan konsumen yang sudah paham, sehingga word of mouth penting bagi perusahaan jasa. Begitu juga dengan perusahaan jasa yang membutuhkan komunikasi word of mouth sebagaimana perusahaan transportasi umum MRT Jakarta. MRT Jakarta merupakan perusahaan transportasi umum yang baru hadir di tengah masyarakat Jakarta memerlukan komunikasi word of mouth yang positif dari penumpangnya untuk menarik orang lain menggunakan jasa layanannya. 
Berdasarkan beberapa paparan di atas, maka dapat disusun suatu kerangka pemikiran yang dikaji gambar 1 berikut ini:

\section{Gambar 1 Kerangka Pemikiran}

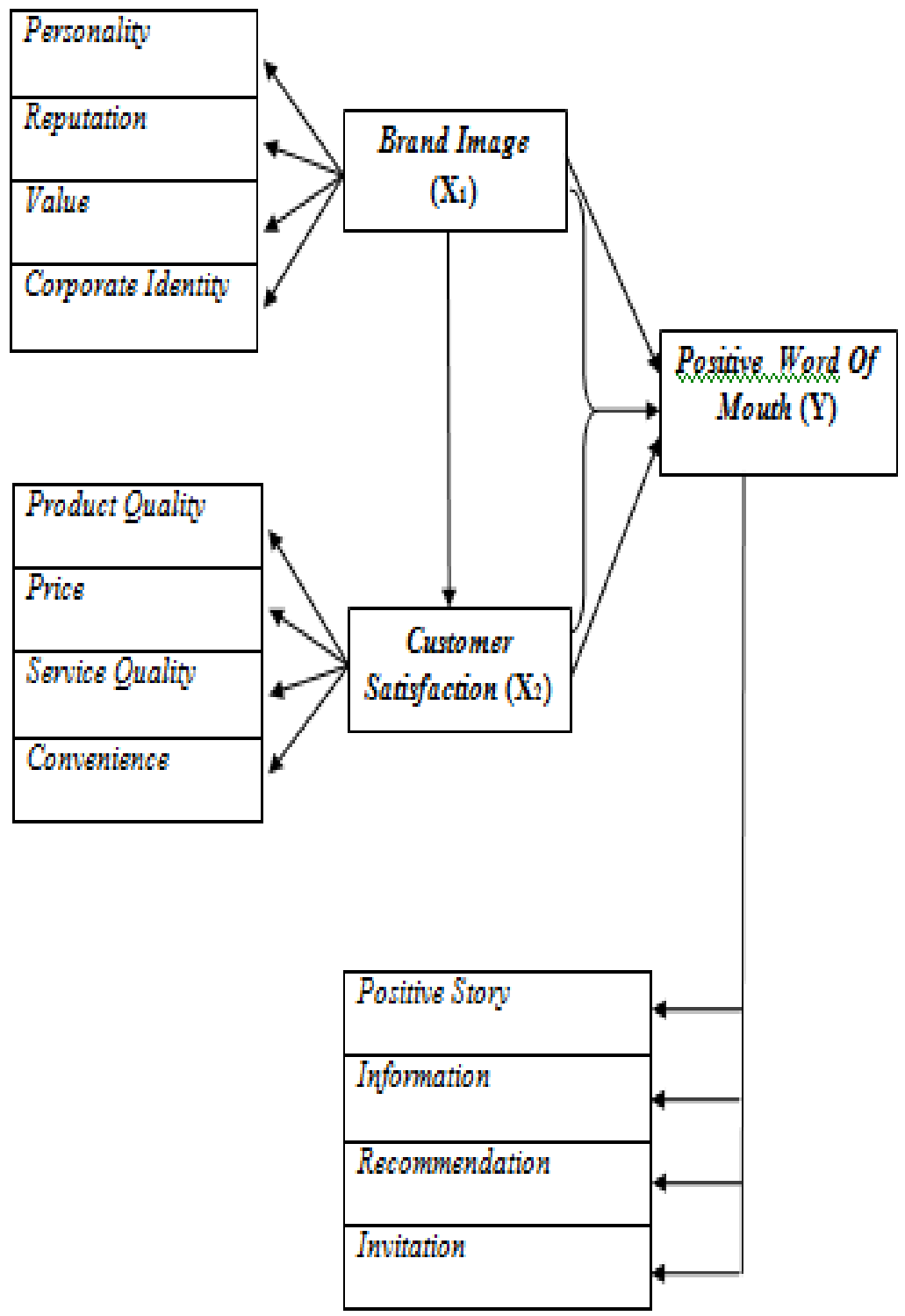

Sumber: Dokumentasi Penulis (2019)

Berdasarkan gambar di atas, menjelaskan alur pemikiran penelitian ini dengan variabel brand image sebagai $\mathrm{X}_{1}$, customer satisfaction sebagai $\mathrm{X}_{2}$ dan positive word of mouth sebagai Y. Kerangka pemikiran diatas mencerminkan apakah ada pengaruh citra merek terhadap positive word of mouth dan implikasinya pada kepuasan penumpang MRT Jakarta. 


\section{Metode Penelitian}

Metode penelitian ini menggunakan metode penelitian kuantitatif dalam bentuk deskriptif. Menurut Bungin (2010:36) penelitian kuantitatif dalam bentuk deskriptif bertujuan untuk menjelaskan berbagai kondisi, situasi, variabel, yang timbul di masyarakat dan menjadi objek penelitian berdasarkan apa yang terjadi dengan responden dari populasi besar. Penelitian ini dilakukan agar setiap variabel yang diteliti dapat diukur sesuai dengan angka yang diperoleh sehingga mendapat kesimpulan akhirnya. Teknik sampling dalam penelitian ini, penulis menggunakan teknik sampling incidental.

Banyaknya responden yang menjadi sampel dari penelitian ini berdasarkan pendapat Hair et.al (dalam Aryani dan Rosinta, 2010:117), yaitu banyaknya jumlah indikator pada penelitian dikali 5. Jumlah indikator dalam penelitian ini sebanyak 24 indikator, sehingga minimal jumlah responden pada penelitian ini adalah $24 \times 5=120$ responden. Akan tetapi, penulis mengambil 125 responden dalam sampel penelitian ini. Untuk mendapatkan data analisis pada penelitian ini penulis mengumpulkan data dengan penyebaran kuesioner dan google form serta data yang diperoleh dari website online seperti Kompas.com dan website Jakartamrt.co.id untuk mendapatkan informasi jumlah penumpang dan informasi-informasi yang terkait dengan MRT Jakarta.

Selanjutnya jawaban responden diolah dengan menggunakan alat ukur skala Likert. Setelah itu, data yang diperoleh dianalisis dengan menggunakan bantuan perangkat lunak SPSS (Statistical Package For The Social Sciences) versi 23 untuk menguji karakteristik responden, validitas dan reliabilitas penelitian, sedangkan teknik pengolahan data SEM (Structural Equation Modelling) menggunakan bantuan perangkat lunak Lisrel versi 8.80 untuk menguji hipotesis penelitian. Menurut Harisuddin (2017:47) jika nilai corrected item total correlation menunjukkan > 0.367 , maka item pernyataan dinyatakan valid. Selanjutnya, Sujarweni dan Utami (2019:77) menyatakan bahwa nilai cronbach alpha's suatu instrumen penelitian dinyatakan reliabel apabila koefisien reliabilitas $>0.7$. Dan untuk menguji hipotesis penelitian digunakan metode pengolahan data SEM dengan Lisrel versi 8.80 dalam nilai $T$ Values. $\left(T\right.$ Values $\left.>\mathrm{T}_{\text {tabel }} 1.96\right)$.

\section{Hasil Temuan dan Diskusi}

Sebanyak $72 \%$ responden penelitian ini berjenis kelamin perempuan dan $28 \%$ lainnya laki-laki. Mayoritas responden $(84,8 \%)$ penelitian ini berumur $20-25$ tahun, sementara $15,2 \%$ dari semua responden mengindikasikan mereka berumur diatas 25 tahun. Profesi responden sebagian besar $(63,2 \%)$ adalah mahasiswa, selanjutnya $29,6 \%$ adalah wiraswasta dan lainnya $7,2 \%$. Responden yang pernah kuliah atau mendapatkan gelar sarjana derajat atau lebih tinggi mewakili 54,4\% dari total sampel dan responden yang telah mencapai pendidikan lainnya sebanyak 45,6\%. 
Meiliana, Rezi Erdiansyah: Pengaruh Citra Merek Terhadap Kepuasan Pelanggan dan Implikasinya pada Positive Word Of Mouth Penumpang MRT Jakarta

Tabel 1. Hasil Uji Validitas

\begin{tabular}{|c|c|c|c|}
\hline Variabel & Indikator & $\begin{array}{l}\text { Corrected } \\
\text { Item Total } \\
\text { Correlation }\end{array}$ & Keterangan \\
\hline \multirow{8}{*}{$\begin{array}{l}\text { Citra Merek } \\
\text { (Brand } \\
\text { Image) }\end{array}$} & $\begin{array}{l}\text { Saya percaya terhadap kualitas jasa layanan } \\
\text { MRT Jakarta. }\end{array}$ & 0.532 & Valid \\
\hline & $\begin{array}{l}\text { Saya mengetahui } \quad \text { keamanan } \\
\text { menggunakan jasa layanan MRT Jakarta. }\end{array}$ & 0.608 & Valid \\
\hline & $\begin{array}{l}\text { Jasa layanan MRT Jakarta memberikan } \\
\text { kemudahan kepada penumpang untuk membeli } \\
\text { tiket menggunakan mesin tiket otomatis. }\end{array}$ & 0.517 & Valid \\
\hline & $\begin{array}{l}\text { nerasa aman dan nyaman menggunakan jasa } \\
\text { layanan MRT Jakarta. }\end{array}$ & 0.556 & Valid \\
\hline & $\begin{array}{l}\mathrm{s} \text { jasa layanan MRT Jakarta cepat tanggap } \\
\text { dalam menangani keluhan saya. }\end{array}$ & 0.569 & Valid \\
\hline & $\begin{array}{l}\text { S MRT Jakarta sangat tulus dan perhatian dalam } \\
\text { berkomunikasi dengan penumpang. }\end{array}$ & 0.670 & Valid \\
\hline & $\begin{array}{l}\text { enang menggunakan layanan jasa MRT Jakarta } \\
\text { karena dianggap menjadi gaya hidup baru } \\
\text { bertransportasi. }\end{array}$ & 0.505 & Valid \\
\hline & engetahui logo jasa layanan MRT Jakarta. & 0.496 & Valid \\
\hline \multirow{8}{*}{$\begin{array}{l}\text { Kepuasan } \\
\text { Pelanggan } \\
\text { (Customer } \\
\text { Satisfaction) }\end{array}$} & $\begin{array}{l}\text { s jasa layanan MRT Jakarta selalu menjaga } \\
\text { kebersihan lingkungan di luar dan dalam MRT. }\end{array}$ & 0.546 & Valid \\
\hline & $\begin{array}{l}\text { enang dengan fasilitas (lift) yang disediakan } \\
\text { oleh jasa layanan MRT Jakarta. }\end{array}$ & 0.532 & Valid \\
\hline & $\begin{array}{l}\text { yang ditawarkan sesuai dengan kualitas yang } \\
\text { diberikan. }\end{array}$ & 0.554 & Valid \\
\hline & $\begin{array}{l}\text { yanan MRT Jakarta memberikan harga yang } \\
\text { terjangkau kepada penumpangnya. }\end{array}$ & 0.591 & Valid \\
\hline & $\begin{array}{l}\text { s jasa layanan MRT Jakarta bersikap ramah dan } \\
\text { sopan dalam berkomunikasi dengan } \\
\text { penumpang. }\end{array}$ & 0.643 & Valid \\
\hline & $\begin{array}{l}\text { s pelayanan petugas jasa layanan MRT Jakarta } \\
\text { sesuai dengan keinginan pelanggan. }\end{array}$ & 0.699 & Valid \\
\hline & $\begin{array}{c}\text { merasa sangat mudah untuk mendapatkan } \\
\text { informasi mengenai jasa layanan MRT Jakarta. }\end{array}$ & 0.495 & Valid \\
\hline & jasa layanan MRT Jakarta strategis. & 0.606 & Valid \\
\hline
\end{tabular}




\begin{tabular}{|c|c|c|c|}
\hline $\begin{array}{l}\text { Positif Word } \\
\text { Of Mouth } \\
\text { (Positive }\end{array}$ & $\begin{array}{l}\text { ingin menceritakan kondisi lingkungan jasa } \\
\text { layanan MRT Jakarta kepada orang lain. }\end{array}$ & 0.669 & Valid \\
\hline \multirow[t]{7}{*}{$\begin{array}{l}\text { Word Of } \\
\text { Mouth) }\end{array}$} & $\begin{array}{l}\text { enang berbagi informasi mengenai pelayanan } \\
\text { petugas jasa layanan MRT Jakarta dengan } \\
\text { orang lain. }\end{array}$ & 0.666 & Valid \\
\hline & $\begin{array}{l}\text { emberikan informasi ketika ditanya orang lain } \\
\text { saja. }\end{array}$ & 0.644 & Valid \\
\hline & $\begin{array}{l}\text { han jasa layanan MRT Jakarta melebihi } \\
\text { keinginan saya, sehingga saya sangat ingin } \\
\text { berbagi informasi ini dengan orang lain. }\end{array}$ & 0.718 & Valid \\
\hline & $\begin{array}{l}\text { angat merekomendasikan orang terdekat saya } \\
\text { untuk menggunakan jasa layanan MRT Jakarta } \\
\text { karena cepat dan nyaman untuk masyarakat } \\
\text { Jakarta yang dinamis. }\end{array}$ & 0.661 & Valid \\
\hline & $\begin{array}{l}\text { nerekomendasikan jasa layanan MRT Jakarta } \\
\text { karena kualitas pelayanan yang diberikan } \\
\text { sangat memuaskan. }\end{array}$ & 0.702 & Valid \\
\hline & $\begin{array}{l}\text { ersedia mengajak orang lain untuk menggunakan } \\
\text { jasa layanan MRT Jakarta. }\end{array}$ & 0.627 & Valid \\
\hline & $\begin{array}{l}\text { lalu mengajak pelanggan lainnya untuk berbagi } \\
\text { pengalamannya ketika menggunakan jasa } \\
\text { layanan MRT Jakarta. }\end{array}$ & 0.600 & Valid \\
\hline
\end{tabular}

Sumber : Data diolah dengan menggunakan SPSS 23

Model pengukuran dengan SPSS versi 23 digunakan untuk mengukur validitas dan reliabilitas. Seperti yang ditunjukkan tabel 1. semua indikator yang mewakili variabel citra merek, kepuasan pelanggan dan positif word of mouth secara signifikan memenuhi persyaratan validitas $(>0.367)$.

Table 2. Hasil Uji Reliabilitas

\begin{tabular}{ccc|}
\hline \multicolumn{1}{c}{ Variabel } & Cronbach's Alpha & Keterangan \\
\hline \multicolumn{1}{c}{ Citra Merek } & 0.827 & Reliable \\
\hline Kepuasan Pelanggan & 0.847 & Reliable \\
\hline 'ositive Word Of Mouth & 0.887 & Reliable
\end{tabular}

Sumber : Data diolah dengan menggunakan SPSS 23 
Meiliana, Rezi Erdiansyah: Pengaruh Citra Merek Terhadap Kepuasan Pelanggan dan Implikasinya pada Positive Word Of Mouth Penumpang MRT Jakarta

Hasil cronbach alpha setiap variabel yang terlihat pada table 2. diatas menunjukkan (>0.7), sehingga semua variabel dinyatakan reliabel.

Tabel 3. Uji Hipotesis dengan Lisrel

\begin{tabular}{|c|c|c|c|c|c|}
\hline Hipotesis & Path & $\begin{array}{l}\text { Standardized } \\
\text { Solution }\end{array}$ & T Values & T Tabel & Keterangan \\
\hline $\mathbf{H}_{1}$ & $\begin{array}{c}\text { Citra Merek } \\
\downarrow \\
\text { Kepuasan } \\
\text { Pelanggan }\end{array}$ & 0.61 & 4.25 & 1.96 & Diterima \\
\hline $\mathbf{H}_{2}$ & $\begin{array}{c}\text { Citra Merek } \\
\downarrow \\
\text { Positive Word } \\
\text { Of Mouth }\end{array}$ & 0.36 & 3.02 & 1.96 & Diterima \\
\hline $\mathbf{H}_{3}$ & $\begin{array}{c}\text { Kepuasan } \\
\text { Pelanggan } \\
\downarrow \\
\text { Positive Word } \\
\text { Of Mouth }\end{array}$ & 0.56 & 4.26 & 1.96 & Diterima \\
\hline $\mathbf{H}_{4}$ & $\begin{array}{c}\text { Citra Merek } \\
\text { dan Kepuasan } \\
\text { Pelanggan } \\
\downarrow \\
\text { Positive Word } \\
\text { Of Mouth }\end{array}$ & 0.70 & 3.28 & 1.96 & Diterima \\
\hline $\mathbf{H}_{5}$ & $\begin{array}{c}\text { Citra Merek } \\
\downarrow \\
\text { Positive Word } \\
\text { Of Mouth } \\
\text { melalui } \\
\text { Kepuasan } \\
\text { Pelanggan }\end{array}$ & 0.42 & 3.53 & 1.96 & Diterima \\
\hline
\end{tabular}

Sumber : Sumber data diolah dari Lisrel versi 8.80

Sesuai dengan model penelitian SEM dengan aplikasi Lisrel versi 8.80, semua hipotesis dapat dilihat dari nilai signifikansi (p) dari masing-masing hasil uji hipotesis. Dengan batas toleransi kesalahan $(\alpha)$ penerimaan dan penolakan hipotesis adalah 5\%. Apabila $\mathrm{p}>\alpha$ atau $<0,05$ dan atau $\mathrm{t}>1.96$ maka terdapat pengaruh yang signifikan antara variabel $\mathrm{X}$ terhadap variabel $\mathrm{Y}$. Secara khusus, citra merek memiliki pengaruh yang signifikan terhadap kepuasan pelanggan $(T$ Values $=4.25$ ) dan positif word of mouth ( $T$ Values $=3.02$ ), dengan demikian hipotesis 1 dan 2 diterima. Kepuasan pelanggan secara signifikan mempengaruhi positif word of mouth ( $T$ Values $=4.26$ ) serta kepuasan pelanggan dan citra merek berpengaruh signifikan terhadap positif word of mouth (T Values $=3.28$ ), hipotesis 3 dan 4 diterima. Selain itu, dapat dilihat bahwa terdapat pengaruh positif dan signifikan dari citra merek melalui kepuasan pelanggan terhadap positif word of mouth penumpang MRT Jakarta ( $T$ Values $=3.53)$. 


\section{Simpulan}

Variabel yang berkontribusi paling besar terhadap positive word of mouth adalah variabel kepuasan pelanggan mouth dengan nilai $T$ Values 4.26 dan nilai standardized solution 0.56 . Dengan demikian, untuk meningkatkan positive word of mouth sangat dipengaruhi oleh kepuasan pelanggan. Dalam membangun kepuasan pelanggan, perlu meningkatkan kualitas pelayanan petugas jasa layanan MRT Jakarta. Selain itu petugas MRT Jakarta harus mampu memenuhi harapan penumpang dengan .meningkatkan kebersihan lingkungan, menetapkan harga yang terjangkau bagi penumpang serta memberikan rasa nyaman terhadap penumpang jasa layanan transportasi umum ini.

\section{Ucapan Terima Kasih}

Peneliti mendapat banyak bantuan, bimbingan, saran dan motivasi dalam proses penulisan skripsi ini. Oleh karena itu, penulis ingin mengucapkan terima kasih kepada Dr. Rezi Erdiansyah, M. Si, selaku Dosen Pembimbing yang sudah banyak membantu dan membimbing dalam penyusunan skripsi ini. Dosen-dosen, orang tua, saudara, sahabat serta semua pihak yang telah memberikan dukungan moral dan materil kepada peneliti.

\section{Daftar Pustaka}

Aryani, Dwi., \& Rosinta, Febrina. (2010). Pengaruh Kualitas Layanan Terhadap Kepuasan Pelanggan Dalam Membentuk Loyalitas Pelanggan. Jurnal Ilmu Administrasi dan Organisasi, 17, 114-126.

Bungin, Burhan. (2010). Metodologi Penelitian Kuantitatif:Komunikasi, Ekonomi, dan Kebijakan Publik serta Ilmu-Ilmu Sosial Lainnya. Jakarta: Kencana.

Harisuddin, Muhammad Iqbal. (2019). Secuil Esensi Berpikir Kreatif dan Motivasi Belajar Siswa. Bandung: PT Panca Terra Firma.

Latief, Rusman. (2018). Word Of Mouth Communication Penjualan Produk. Surabaya: Media Sahabat Cendekia.

Mira, Abolghasem,. \& et. al. (2014). The Role of Excitement and Brand Image in Word Of Mouth. European. Journal of Business and Management, 6, 170178

Popp, Bastian. (2017). Consumer-Brand Identification Revisited: An Integrative Framework of Brand Identification, Consumer Satisfaction, and Price Image and their Role for Brand Loyalty and Word of Mouth. Journal of Brand Management, 24, 250-270.

Prasetyo, D. Bambang, et. al. (2018). Komunikasi Pemasaran Terpadu (Pendekatan Tradisional Hingga Era Media Baru). Malang: UB Press.

Putri, Nindira Rossellini dan Fendy, Suhariadi. (2013). Hubungan Antara Kepuasan Pelanggan dengan Word Of Mouth Pada Pelanggan Klinik Kecantikan London Beauty Care. Jurnal Psikologi Industri dan Organisasi, 2, 169-176 
Meiliana, Rezi Erdiansyah: Pengaruh Citra Merek Terhadap Kepuasan Pelanggan dan Implikasinya pada Positive Word Of Mouth Penumpang MRT Jakarta

Sallam, Methaq Ahmed. (2014). The Effects Of Brands Image and Brand Identification on Brand Love and Purchase Decision Making: The Role of WOM. International Business, 7, 187-193

Santoso, Devita Agustin, Rezi Erdiansyah, \& Muhammad Adi Pribadi. (2018). Pengaruh Brand Awareness dan Brand Image Terhadap Minat Beli Produk Kecantikan Innisfree. Prologia, 2, 286-290.

Sugianto, La Ode. (2016). Antecedent And Konsekuen Word Of Mouth. Jurnal Ekonomi Syariah, 4, 155-178.

Sujarweni, Wiratna dan Utami. (2019). Pintar Mengolah Data Statistik Untuk Segala Keperluan Secara Otodidak. Yogyakarta: Start up.

Sukoco, Sampir Andrean. (2018). New Komunikasi Pemasaran: Teori dan Aplikasinya. Jawa Timur: CV Pustaka Abadi. 